\title{
Combining of Radionuclides with Constituent Materials of Marine Algae
}

\author{
Ryoichi NAKamurA*1, Motokazu NAKaHARA*1, Toshiaki IshiI ${ }^{* 1}$, \\ Taishi UEDA*1, and Chiaki SHIMIzU ${ }^{* 2}$
}

(Received January 5, 1979)

\begin{abstract}
The relations between the accumulation-elimination of radionuclides and the constituent materials of marine algae were studied to determine more precisely the mechanism of the radioactive contamination of marine organisms. This will increase the information about the behavior of radionuclides in marine organisms in relation to the environmental conditions (temperature, physico-chemical state of radioisotope, and so on) and the biological conditions (feeding habits, species, and so on).

Eisenia contaminated by ${ }^{137} \mathrm{Cs}$ and ${ }^{106} \mathrm{Ru}-{ }^{100} \mathrm{Rh}$ was fractionated by solvent extraction into 6 fractions. The largest portion of ${ }^{177} \mathrm{Cs}$ was in the boiling water fraction; ${ }^{108} \mathrm{Ru}-{ }^{106} \mathrm{Rh}$ was most extracted by $24 \% \mathrm{KOH}$ solution. Elution patteras by Sephadex G-100 gel-filtration of samples differed largely from each other, both among the 3 kinds of radionuclides and between the 2 species of the algae. Therefore, the accumulation of the radionuclides by the marine algae was proved to be not only due to a physical adsorption to the surface of the algae but also to the biological combining of the radionuclides with the constituents of the algae. Furthermore, it was found that radionuclides which combine with a few constituents of alga are not eliminated equally. This is considered to be useful for the physiological analysis of elimination curves.
\end{abstract}

Hitherto, studies on the radioactive contamination of marine organisms have been mainly focused on the relations of uptake and elimination of radioactive substances to their environmental (in other words, external) conditions such as temperature of sea water ${ }^{1,21}$, illumination ${ }^{3,4}$, physicochemical state of the radioisotopes in sea water ${ }^{5}$, effects of marine sediment ${ }^{6-10\}}$ and corelation with concentration of stable elements ${ }^{11}$; or to their biological conditions such as stages of their growth $^{12,18)}$, feeding habits ${ }^{14-16)}$, and species ${ }^{711}$. However, very little is known about the relations between radionuclides in organisms and constituent materials of the organisms.

Information about the relation between radionuclides and the constituent materials of marine organisms would give us a knowledge of the behavior of radionuclides in marine organisms, that is, knowledge of components which compose an elimination curve of a radionuclide for a marine organism. Further, the information would add precision to the results of investigation on the radioactive contamination of marine organisms. With all these investigations, the mechanism of radioactive contamination of marine organisms could be clarified.

Therefore, in this article, the relations between accumulation-elimination of radionuclides and constituent materials of marine algae were studied, not neglecting whether the accumulation of radionuclides by marine algae is only a physical adsorption to the surface of the algae or a physiological absorption by special constituents of the algae.

\section{Materials and Methods}

Uptake and Loss of Radionuclides by Marine Algae Brown alga (Eisenia bicyclis) was obtained at the coast of Hitachi (Ibaraki) and green alga (Ulva pertusa) was taken at Nakaminato (Ibaraki). Nine hundred grams of each species was reared individually in $150 \mathrm{l}$ of sea water with radionuclides for a week. The rearing system was equipped with sufficient air supply, a thermoregulator of sea water $\left(20 \pm 2^{\circ} \mathrm{C}\right)$ and illumination of $4,500 \mathrm{lux}$ on the surface of the rearing sea water. Radionuclides were added separately into the sea water of the respective aquarium a day before putting algae into aquaria. They were ${ }^{60} \mathrm{Co}\left(\mathrm{CoCl}_{2}\right),{ }^{137} \mathrm{Cs}(\mathrm{CsCl})$

*1 Division of Marine Radioecology, National Institute of Radiological Sciences, Isozaki, Nakaminato, Ibaraki 311-12, Japan (中村良一，中原元和，石井紀明，上田泰司：放射線医学繶合研究所).

*2 Laboratory of Fisheries, Faculty of Agriculture, University of Tokyo, Maisaka, Shizuoka 431-02, Japan (清水千秋：東京大学農学部附属水産実駰所). 
and ${ }^{106} \mathrm{Ru}-{ }^{106} \mathrm{Rh}$ (nitrosylruthenium nitorato complexes). The specific activity of ${ }^{60} \mathrm{Co}$ was $93 \mathrm{mCi} / \mathrm{mg}$ and other radionuclides were carrier free.

After a week, a part of the algae was taken up out of the radioactive sea water for analyses. The rest of the algae was transferred to nonradioactive fresh sea water and reared under the same experimental condition for 32 days. During the period, portions of the algae were taken out of the aquaria on the $2 \mathrm{nd}, 5$ th, 14 th and $32 \mathrm{nd}$ days after the transference of the algae to the fresh sea water. The prepared samples of the algae were analyzed by solvent extraction and gel filtration. Samples for solvent extraction were boiled in fresh sea water for 5 minutes immediately after being taken out of the aquaria and air-dried on filter paper, whereas, samples for gel filtration were kept frozen until the analyses were carried out.

\section{Fractionation by Solvent Extraction}

Dried samples were treated according to the procedure shown in Fig. 1. Extractable materials in each fraction were also listed. About $40 \mathrm{~g}$ of sample was boiled in $200 \mathrm{ml}$ of ethyl ether in a water bath for 24 hours and this extraction was repeated 3 times (Ether fraction). The residue from ether extraction was boiled in $200 \mathrm{~m} l$ of $80 \%$ ethyl alcohol for 1 hour and this procedure was also repeated 3 times (Ethanol fraction). In the next process, the residue was boiled for 1 hour in distilled water $(200 \mathrm{~m} l)$ and two more repetitions were performed (Boiling water fraction). The residue was air-dried on filter paper and steeped in $500 \mathrm{ml}$ of $0.2 \% \mathrm{NaOH}$ solution and kept standing for 24 hours with occasional agitation $(\mathrm{NaOH}$ fraction). After the separation by decantation, $500 \mathrm{~m} l$ of $24 \% \mathrm{KOH}$ solution was added to the dreg and the mixture was left standing for 24 hours. Then, the mixture was centrifuged to separate supernatant from residue ( $\mathrm{KOH}$ fraction).

One $\mathrm{ml}$ of each fraction was put into an acrylic counting test tube for the measurement of radioactivity by a well-type $r$-ray counter with an automatic sample changer (Aloka auto well gamma system, JDC-752). The ratio of radioactivity in each fraction to the total radioactivity in the original dried sample was calculated.

\section{Gel-Filtration}

Crude extract was prepared from the frozen sample of marine algae. Samples $(0.5-1.0 \mathrm{~g})$ were homogenized with about $15 \mathrm{ml}$ of $0.025 \mathrm{M}$ Trisacetate buffer solution ( $\mathrm{pH} \mathrm{8.4)} \mathrm{by} \mathrm{a} \mathrm{high} \mathrm{speed}$ homogenizer $(20,000 \mathrm{rpm})$ and centrifuged at $10,000 \mathrm{rpm}$ for 40 minutes. This procedure was repeated twice. A portion $(5-10 \mathrm{~m} l)$ of the extracted solution was applied to a Sephadex G100 gel column $(2 \times 75 \mathrm{~cm})$ equilibrated with the above buffer. The gel filtration was performed in a descending system using the same buffer. Each $5 \mathrm{ml}$ of fraction was collected and the radioactivities in the fractions were measured by the same $\gamma$-ray counter as mentioned above.

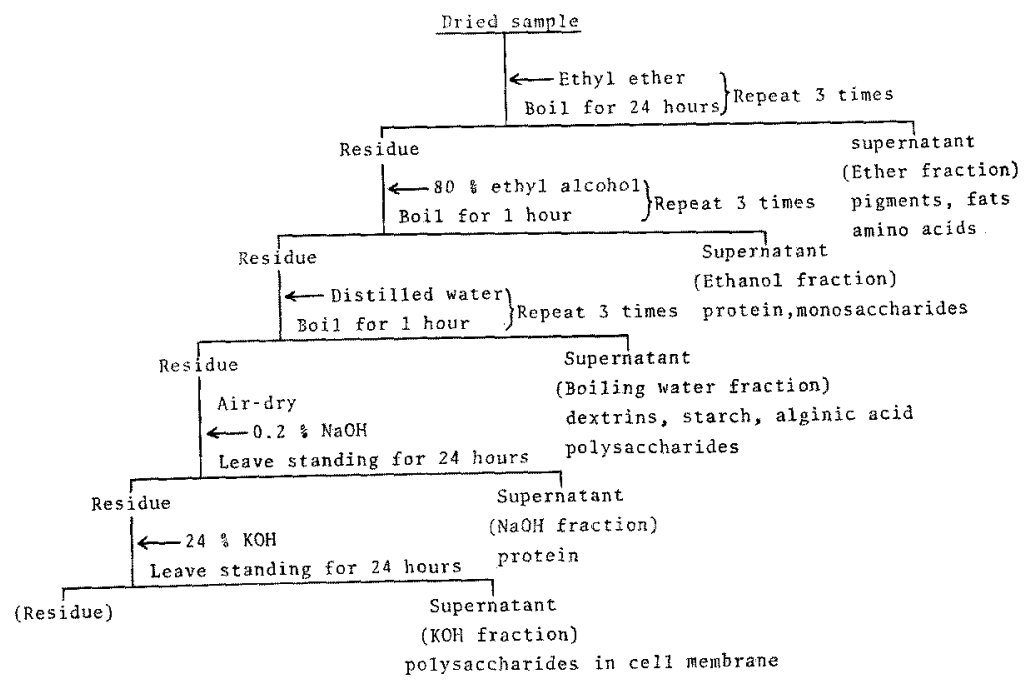

Fig. 1. The procedure applied to the fractionation of constituents of Eisenia bicyclis. 


\section{Results and Discussion}

\section{Fractionation of Eisenia Bicyclis by Solvent Ex- traction}

When boiled in fresh sea water for 5 minutes, samples lost several percent of their radioactivity into the boiling sea water. Distribution of radioactivity of ${ }^{137} \mathrm{Cs}$ and ${ }^{106} \mathrm{Ru}-{ }^{106} \mathrm{Rh}$ in each fraction shown in Table 1 was the result from the Eisenia samples taken up on the 7 th day after the start of

Table 1. Distributions $(\%)$ of radionuclides accumulated in Eisenia bicyclis among fractions

\begin{tabular}{lcc}
\hline \hline Fraction & ${ }^{137} \mathrm{Cs}$ & ${ }^{100} \mathrm{Ru}-{ }^{108} \mathrm{Rh}$ \\
\hline Ether & $0.4 \%$ & $0 \%$ \\
Ethanol & 40.6 & 1.7 \\
Boiling water & 43.1 & 29.3 \\
NaOH & 6.8 & 1.2 \\
KOH & 7.4 & 44.1 \\
Residue & 1.7 & 23.7 \\
\hline
\end{tabular}

the uptake experiment. Both radionuclides were scarcely detected in the ethyl ether fraction that was supposed to extract pigments, fats and amino acids. In the following process, about $40 \%$ of the initial amount of ${ }^{187} \mathrm{Cs}$ was found in the $80 \%$ ethyl alcohol fraction, whereas, ${ }^{106} \mathrm{Ru}-{ }^{106} \mathrm{Rh}$ was extracted little in the fraction. Considerable amount of the radionuclides was stripped out of the residues by boiling water which mainly extracts dextrins and polysaccharides such as starch and alginic acid. ${ }^{137} \mathrm{Cs}$ was detected a little in the fraction of $0.2 \% \mathrm{NaOH}$ solution by which protein could be extracted and ${ }^{106} \mathrm{Ru}-{ }^{106} \mathrm{Rh}$ was little in the fraction. Unlike ${ }^{187} \mathrm{Cs},{ }^{106} \mathrm{Ru}-{ }^{106} \mathrm{Rh}$ was well detected in the fraction of $24 \% \mathrm{KOH}$ solution which is responsible for the extraction of dissolving polysaccharides, probably in cell membrane or wall. Fig. 2 shows the variation of distribution of radionuclides in fractions during loss experiment, supposing that the total radioactivities of the samples are $100 \%$ on the 7 th day of the uptake experiment. Radioactivity in each fraction seems to become lower in proportion to the decrease of total radioactivity in the sample with the passing of day. The sum of radioactivity of ${ }^{137} \mathrm{Cs}$ in $80 \%$ ethanol and boiling water fractions was about $80 \%$ of the total radioactivity in each sample at each sampling time but that of ${ }^{106} \mathrm{Ru}-{ }^{106} \mathrm{Rh}$ was only about $30 \%$. These figures were similar to the extraction percent mentioned later in gel-filtration. In spite of the same constituents in the alga, large difference was observed between distributions $(\%)$ of ${ }^{137} \mathrm{Cs}$ and
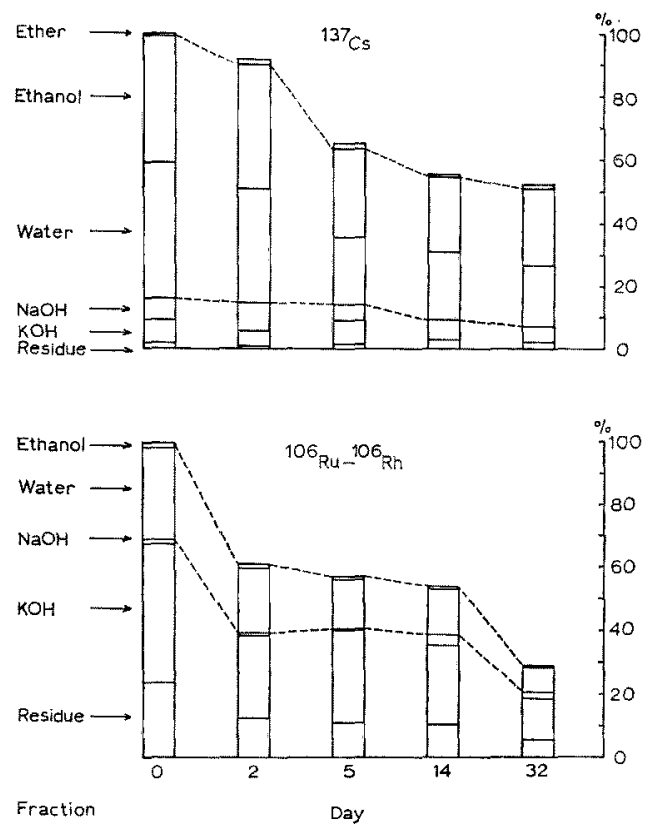

Fig. 2. Variation of the distribution of radionuclides among the fractions.

${ }^{106} \mathrm{Ru}-{ }^{106} \mathrm{Rh}$ in most fractions. This large difference suggests that there is the biologically meaningful combining of radionuclides with the constituents of the brown alga. In other words, the accumulation of the radionuclides by the brown alga does not always result merely from physical binding of the nuclides to the surface materials of the alga.

\section{Gel-Filtration}

Gel-filtration was tried to obtain further knowledge about the relation between radionuclides and the constituents of the algae.

Extraction percent of radionuclides from algae by homoginizing was shown in Table 2 . Figures

Table 2. Extraction percent of crude extracts from marine algae

\begin{tabular}{lcc}
\hline & Eisenia bicyclis & Ulva pertusa \\
\hline${ }^{60} \mathrm{Co}$ & $67 \%$ & $47 \%$ \\
${ }^{137} \mathrm{Cs}$ & $73 \%$ & $66 \%$ \\
${ }^{108} \mathrm{Ru}-{ }^{100} \mathrm{Rh}$ & $23 \%$ & $14 \%$
\end{tabular}

for ${ }^{60} \mathrm{Co}$ and ${ }^{137} \mathrm{Cs}$ were almost around $70 \%$ but those for ${ }^{106} \mathrm{Ru}^{-}{ }^{106} \mathrm{Rh}$ were small. Fig. 3 shows the elution patterns of the column chromatography on Sephadex G-100 gel. Yield of radioactivity in 

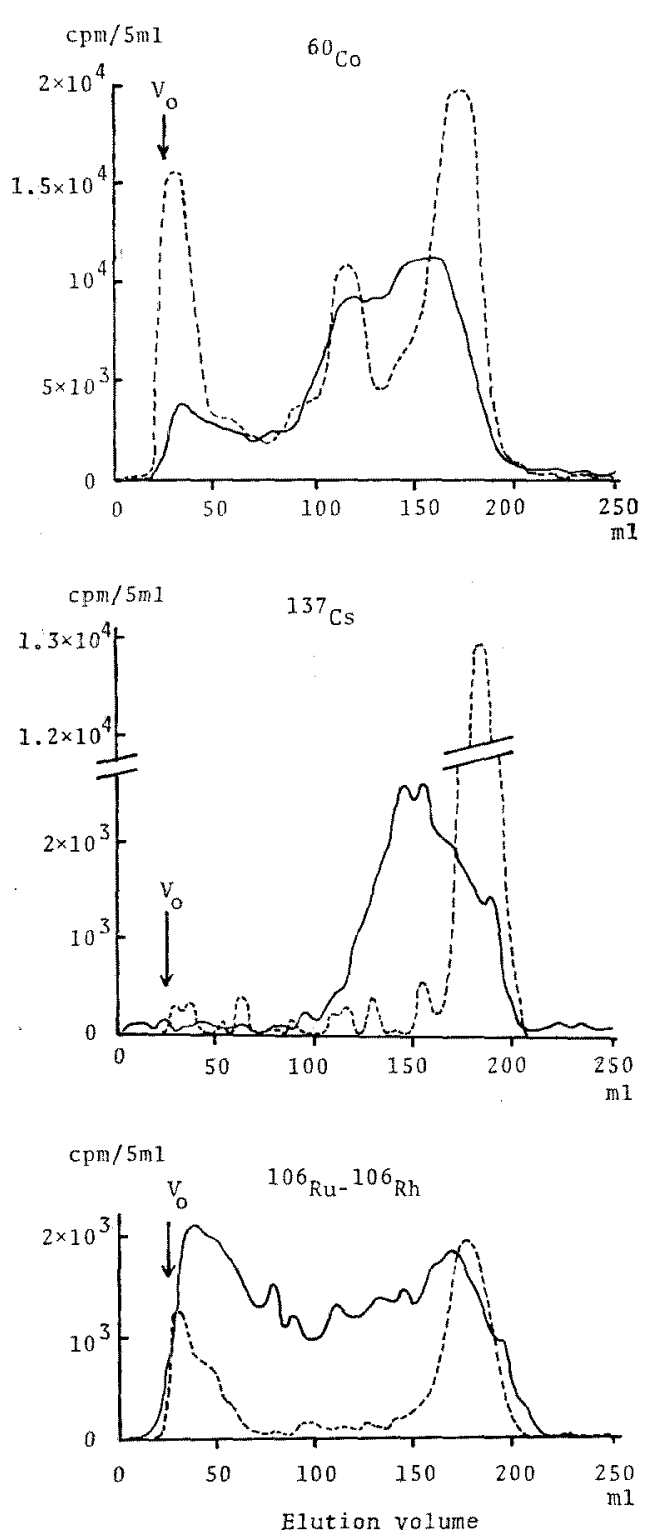

Fig. 3. Sephadex G-100 gel-filtration of crude extracts from algae at the start of the loss experiment. Solid line: Eisenia bicyclis, broken line: Ulva pertusa. The sample was eluted with 0.025 M Tris-acetate buffer, $\mathrm{pH} 8.4$, at the flow rate of $20 \mathrm{~m} / / \mathrm{hr}$.

the total elution volume $(250 \mathrm{~m} l)$ was almost $100 \%$. Fairly large difference of the elution patterns was observed, not only among the three kinds of radionuclides but also between the two species of the algae. The chromatography of green alga is nor- malized to the same weight of brown alga.

Chromatography of crude extract from green alga is simpler than that from brown alga. Although ${ }^{60} \mathrm{Co}$ and ${ }^{106} \mathrm{Ru}-{ }^{106} \mathrm{Rh}$ combine with many kinds of constituents, ${ }^{137} \mathrm{Cs}$ combines with the constituents having relatively small molecular weights. Observing the destruction of the cell wall by high speed homogenizer with a microscope, it was assumed that most part of the radionuclides in the extract of green alga was derived from intracellular materials of the alga. Therefore, considering fairly large extraction percent of ${ }^{137} \mathrm{Cs}$ and ${ }^{60} \mathrm{Co}$, it is estimated that the accumulation of these radionuclides in alga is related to metabolism. GuTKNECHT ${ }^{41}$ reported that ${ }^{187} \mathrm{Cs}$ was not extensively adsorbed by cell wall of Ulva, nor by killed tissue of 9 species of algae used in his experiment, and $\mathrm{Cs}$ movement was closely related to metabolism.

Combining of ${ }^{106} \mathrm{Ru}-{ }^{106} \mathrm{Rh}$ with constituents in the extract from green alga indicates to be a biological phenomenon, because ${ }^{106} \mathrm{Ru}-{ }^{106} \mathrm{Rh}$ does not combine with the constituents which combines with ${ }^{60} \mathrm{Co}$ (Fig. 3).

However, extraction percent of ${ }^{106} \mathrm{Ru}-{ }^{106} \mathrm{Rh}$ from the algae was very small, namely there was only a little ${ }^{106} \mathrm{Ru}-{ }^{106} \mathrm{Rh}$ in the extract containing constituents, which were considered to be derived from intracellular materials of the algae. Constituents in the cell walls and intercellular spaces of the algae could hardly be extracted by homogenizing, because homogenizing could not dissolve the cell walls though it could tear and break them. Therefore, with the buffer solution, most of the radionuclide not extracted from the homogenized algal sample is expected to be present in the cell walls and/or intercellular spaces. JoNEs ${ }^{17}$ found that alginic acid, both as the free acid and the sodium salt, combines with ${ }^{106} \mathrm{Ru}$ and reported that the uptake of nitrosyl ${ }^{106} \mathrm{Ru}$ by Porphyra laciniata, Ulva lactuca and Laminaria digitata is also a surface phenomenon, besides, the ${ }^{106} \mathrm{Ru}$ complexes with the extracellular polysaccharide materials and difference in accumulation of ${ }^{106} \mathrm{Ru}$ among these algae may be due to difference in the chemical nature of the extra-cellular material. The polysaccharide is found in the cell walls and intercellular spaces and it is an ion-exchange material $^{181}$.

The expectation regarding whereabout of the accumulated ${ }^{106} \mathrm{Ru}-{ }^{106} \mathrm{Rh}$, was confirmed by the fact that ${ }^{106} \mathrm{Ru}-{ }^{106} \mathrm{Rh}$ was largely extracted by $24 \%$ $\mathrm{KOH}$ which must have dissolved the materials of 

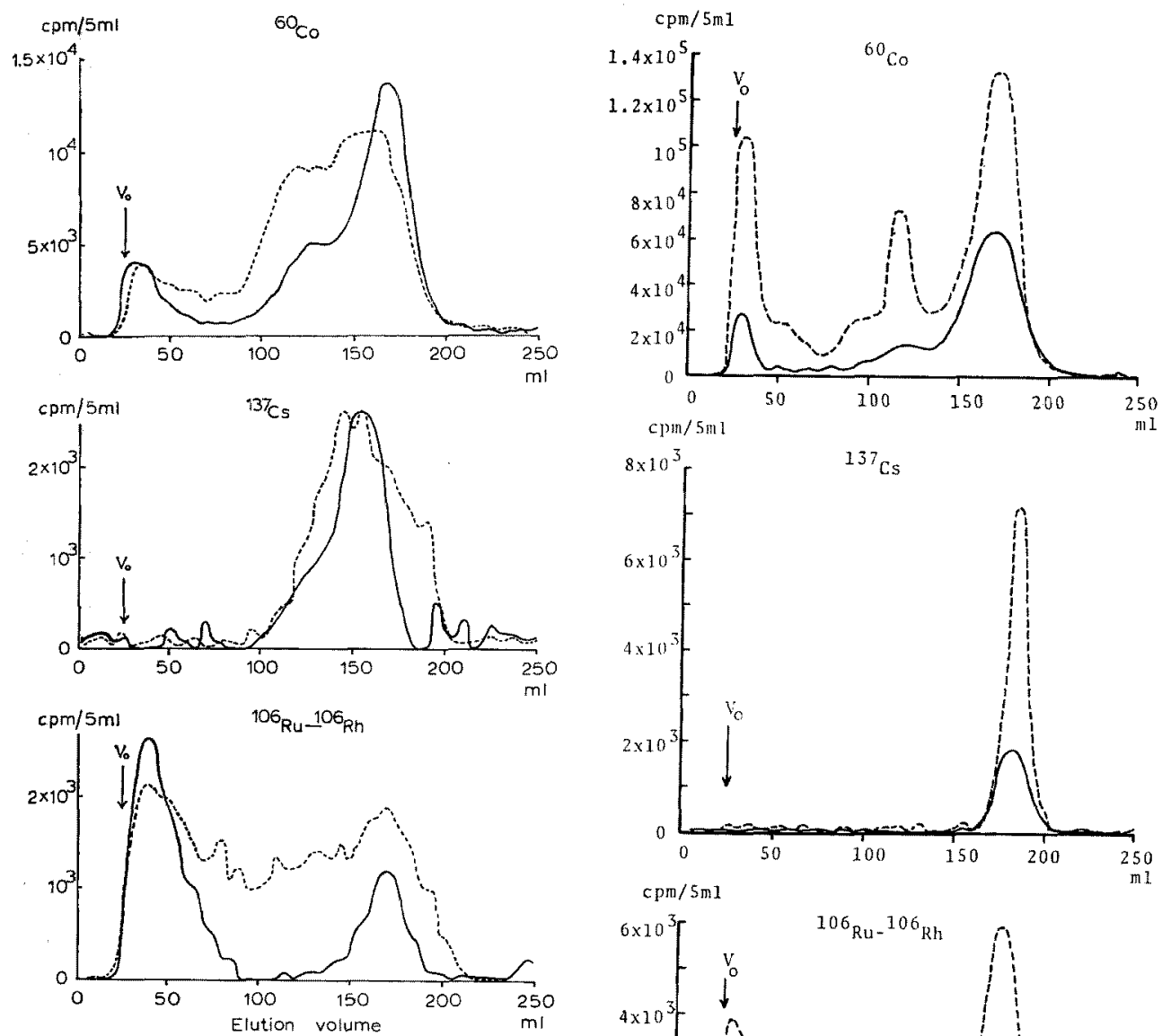

Fig. 4. Sephadex G-100 gel-filtration of crude extracts from Eisenia bicyclis. Solid line: sample taken up on the 5th day since the start of the loss experiment. Broken line: sample at the start of the loss experiment. The sample was eluted with $0.025 \mathrm{M}$ Tris-acetate buffer, $\mathrm{pH} 8.4$, at the flow rate of $20 \mathrm{~m} / \mathrm{hr}$.

the cell walls in the fractionation by solvent extraction described above. A result of the fractionation suggests that fat scarcely accumulates such radionuclides as ${ }^{137} \mathrm{Cs}$ and ${ }^{106} \mathrm{Ru}-{ }^{106} \mathrm{Rh}$. Both biuret test and coloration of ninhydrin were negative in any portion of the eluted solution.

Chromatographies for the algae reared for 5 days in the loss experiment, are shown in Fig.s 4 and 5. Broken lines indicate the chromatographies for the algae at the start of the loss experiment.

Rearing for 5 days in fresh sea water reduced ${ }^{60} \mathrm{Co}$ in brown alga to $86 \%$ of the initial concentration, ${ }^{137} \mathrm{Cs}$ to $65 \%$ and ${ }^{106} \mathrm{Ru}-{ }^{108} \mathrm{Rh}$ to $57 \%$. In case of green alga, remaining radioactivity after

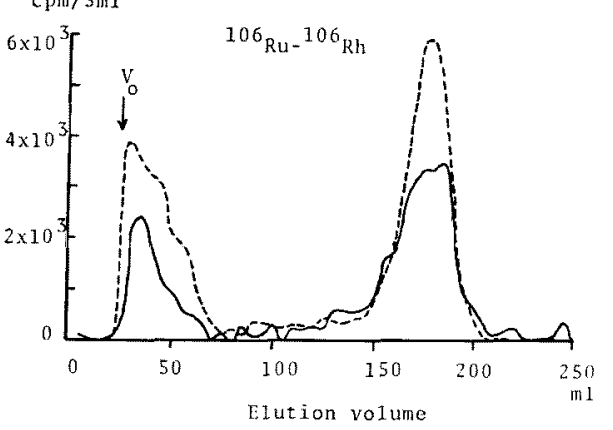

Fig. 5. Sephadex G-100 gel-filtration of crude extracts from Ulva pertusa. Solid line: sample taken up on the 5th day since the start of the loss experiment. Broken line: sample at the start of the loss experiment. The sample was eluted with $0.025 \mathrm{M}$ Tris-acetate buffer, $\mathrm{pH} \mathrm{8.4}$, at the flow rate of $20 \mathrm{~m} / / \mathrm{hr}$.

5 days rearing was $58 \%$ of the initial concentration for ${ }^{60} \mathrm{Co}, 38 \%$ for ${ }^{187} \mathrm{Cs}$ and $31 \%$ for ${ }^{106} \mathrm{Ru}-{ }^{106} \mathrm{Rh}$. It is perceptible in Fig. 4 that during the first 5 days, ${ }^{60} \mathrm{Co}$ was removed mainly from constituents which eluted between 100 and $150 \mathrm{ml}$, whereas, the largest molecular weight peak was not varied 
and the peak between 150 and $200 \mathrm{ml}$ tended to increase during the period. Unlike in brown alga, all of 3 peaks of ${ }^{60} \mathrm{Co}$ in green alga decreased considerably. Rearing the algae in fresh sea water for 5 days, ${ }^{106} \mathrm{Ru}-{ }^{106} \mathrm{Rh}$ combined with constituents of the brown alga reduced largely, between 70 and $150 \mathrm{~m} l$ of elution volume, but two peaks of ${ }^{106} \mathrm{Ru}-$ ${ }^{106} \mathrm{Rh}$ in green alga decreased at similar rates. As shown in Fig. 5, decreasing rates of the peaks of ${ }^{60} \mathrm{Co}$ are not always the same. For 5 days, ${ }^{60} \mathrm{Co}$ combined with constituents which have the largest molecular weights (the left side peak), decreased most to $23 \%$ of the initial radioactivity. Whereas, the middle and the right side peaks reduced to $26 \%$ and $67 \%$ of the initial height respectively within 5 days.

From results described above, it is obvious that the loss of radioactivity from constituents of algae in the fresh sea water, varies according to the species of algae and kinds of radionuclides.

Until now, mathematical method has been applied to find component lines out of an elimination curve which shows decrease of radioactivity in a marine organism in fresh sea water. However, it will be biologically and physiologically more meaningful to take account of constituents of marine organisms combined with radionuclides and the decreasing rates of the nuclides in the constituents.

\section{References}

1) C.E. Styron, T. M. Hagan, D. R. Campbell, J. Harvin, N. K. WhitTenburG, G. A. Baugh- man, M. E. Bransford, W. H. Saunders, D. C. Williams, C. Woodle, N. K. Dixon, and C. R. MC-NeIll: J. Mar. Biol. Ass. U.K., 56, 13-20 (1976).

2) M. Nakahara, T. KoYanagi, and M. SaIKI: J. Radiat. Res., 18, 122-131 (1977).

3) G. W. BRYAN: J. Mar. Biol. Ass. U.K., 49, 225243 (1969).

4) J. GutKNECHT: Limnol. Oceanogr., 10, 58-66 (1965).

5) IAEA Laboratory Activities, 7th Report, Tech. Rep. Ser. No. 103, IAEA, Monaco, 73-74 (1970).

6) T. Ueda, R. Nakamura, and Y. Suzukr: $J$. Radiat. Res, 18, 84-92 (1977).

7) T. Ueda, R. Naxamura, and Y. Suzuki: $J$. Radiat. Res., 19, 93-99 (1978).

8) Y. SuzukI, R. Nakamura, and T. Ueda: I. Radiat. Res., 17, 115-126 (1976).

9) R. Nakamura, Y. Suzuki, and T. UEDa: J. Radiat. Res., 16, 224-236 (1975).

10) R. Nakamura, Y. Suzuki, and T. Ueda: J, Radiat. Res., 18, 322-330 (1977).

11) T. Ismi, H. SuzukI, and T. Koyanagi: Bull. Japan. Soc. Sci. Fish., 44, 155-162 (1978).

12) C. R. Boyden: J. Mar. Biol. Ass. U.K., 57, 675-714 (1977).

13) E. P. Odum: Biol. Bull, 121, 371-372 (1961).

14) M. NAKahara and F. A. Cross: Bull. Japan. Soc. Sci. Fish., 44, 419-425 (1978).

15) M. L. Young: J. Mar. Biol. Ass. U.K., 55, 583-610 (1975).

16) J. Shulman, I. L. Brisbin, and W. Knox: Biol. Bull., 121, 378 (1961).

17) R. F. JoNes: Limnol. Oceanogr., 5, 312-325 (1960).

18) W.A.P. BlACK and R. L. Mrtchell: $J$, Mar. Biol. Ass. U. K., 30, 575-584 (1952), 